\title{
Problem Solving Method On The Topic Of Fraction
}

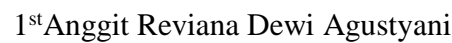 \\ Department of Mathematics, \\ Universitas Negeri Padang \\ Padang, Indonesia \\ anggit_reviana@fmipa.unp.ac.id
}

\begin{abstract}
The development of science about learning has offered a variety of learning methods that can be used to improve student learning achievement. One of them is a problem solving method that can improve problem solving abilities. However, reality in schools, teachers still prefer to use the expository method. To apply the problem solving method at school needs to do research first. Therefore, this study aims to investigate whether the problem solving method produces students'mathematics learning achievement that is better compared to the expository method. One of topics in math that students usually make errors is fraction, so this study attempt to discover the effect of problem solving and expository method on the topic of fraction. This study is semi-experimental. The population were seventh grade students of junior high school in Surakarta. Samples were recruited by using cluster random sampling technique. The samples are 2 classes with a total of 60 students, one class as an experimental class and the other class as a control class. Data collection methods used are documentation methods and test methods. The data analysis technique used is the $t$ test. The results shows that problem solving learning methods provide learning achievements that are as good as expository learning methods on the topics of fraction.
\end{abstract}

Keywords-problem solving, expository, fraction

\section{INTRODUCTION}

The result of teaching and learning process are outputs which are generally referred to as learning achievement. Learning achievement can be achieved by a learner through effort during the learning process. However, many factors influence learning achievement as well as the learning process. These factors are come from within the individual himself and outside the individual. To get the expected student learning achievement, teacher must be able to create a pleasant learning atmosphere, and make students participate actively in learning activities by paying attention to all the factors involved. This atmosphere can be created through the selection of various appropriate learning methods.

Based on the results of observations on teachers of SMP Negeri 16 Surakarta, the teacher usually uses expository method in teaching. Teacher explains, gives examples of questions, then gives practice questions to students, while students listen, record and do the questions requested by the teacher. From the results of interviews with teachers, student achievement is still at a standard level, not too bad, but not too good. This may be influenced by the state of passive students in teaching and learning activities, the teacher cannot see whether students actually understand the material well or not. Students do not optimize their ability to solve questions because they tend to wait for the answers given by the teacher. In order to be able to understand the topic, solve problems correctly, and can optimize their abilities, students need to be trained to ask questions and think mathematically to find a solution of a problem. A method where the teacher can help students to optimize their mathematical thinking skills is problem solving.

Problem solving methods change the passive position of students to become students who are actively enganging in learning process. As a consequence, it requires changing the role of the teacher. Teachers need to be really involved in stimulating students to actively think. According to Polya, one of the originators of problem solving theory, the teacher must exert all of his abilities to build students' ability to solve problems. Why is this important? The first reason is because students (even teachers, principals, parents, and everyone) are always faced with a problem every day, consciously or not. Therefore learning early problem solving is needed so that students can solve their life problems. In his book, Polya [1] states that a mathematics teacher has a great opportunity to challenge his students by giving unusual problems, problems that proportionate to his students'knowledge, and gives stimulation question to the students in order to create students'independent thinking. That is why problem solving is also a way of thinking. Problem solving helps us improve logical reasoning abilities. Problem solving involves students 'emotions during the problem solving process, it can also challenge students' minds and nuances so that they can increase their curiosity, motivation and persistence to always be involved in mathematics.

Most students still consider mathematics as a difficult lesson to learn, this may cause students not to be interested in mathematics, so the need for appropriate learning methods that can make students more interested and more happy in learning mathematics.

One of the mathematics materials taught in junior high school is fractions. The development of students' knowledge about fractions starting from elementary school then continued in junior high school and used until students are in college later. Based on the experience of teachers of SMP Negeri 16 Surakarta, student achievement on the subject of fractions has not been satisfactory, with completeness criteria of at least 63, students who have just completed $67 \%$. There are still many students who are false in answering fraction questions. For example, $1 / 2$ is written as $11 / 2,2 / 3+5 / 3=7 / 6$ and $1 / 2 \times 1 / 4=1 / 6$. Students'errors in solving these fraction problems are caused by a lack of students' understanding of fractional counting operations (including addition, subtraction, multiplication and division). Problem in the form of story questions, students also still have difficulties in 
solving the problem, students often cannot model the question in the form of fractions.

In fractions, there are still difficulties in solving problems. For example, students can smoothly solve $2 \times 4$ questions, but solving the $1 / 2 \times 4$ problem is not easy. To calculate $1 / 2 \times 1 / 3$ is even more difficult, because students do not have basic experience to count $1 / 3$ times. Another major difficulty in fractions is in adding up and subtracting fractions. For example in natural numbers, it can be directly calculated as $3+4$, but in $1 / 3+1 / 4$ fractions it is not easy to calculate for students, because 3 and 4 in the fraction cannot be added directly.

From these problems, the author tries to find solutions to improve students' understanding of fraction material through problem solving methods, where in this method students have the opportunity to further improve their mathematical thinking skills.

Based on these problems, researcher conduct research to answer the question: Is mathematics learning on the subject of fractions using problem solving methods will provide better mathematics learning achievement compared to mathematics learning using the expository method?

\section{REVIEW OF LITERATURE}

Teaching methods can be interpreted as the right ways so that teachers can succeed in teaching. Teaching method is very useful especially for teachers as an effort to improve student learning outcomes. In principle, none of the teaching methods can be considered perfect and match all the subjects in each field of study, each teaching method must have advantages and disadvantages.

The expository method is the most popular and widely used method of the teacher. Expository method is done in a way, teacher conveys the learning material to students by organizing, sorting and completing existing material carefully, students then receive the materials or listen to the teacher's explanation, and carry out the teacher's instructions.

This method is teacher-centered, which is used to transfer experience and information to students by giving prior information and all material of subject matter as well as providing examples and exercises in the form of lectures. Almost all activities are teacher-centered and all teaching activities are controlled by the teacher, without any effort to find and apply different learning strategies according to the theme.

Another method is problem solving. What is problem solving? The term problem solving is often used in various fields of science and has different meanings. But problem solving in mathematics has its own peculiarities. There are three types of interpretations of the terms problem solving in mathematics learning, namely (1) problem solving as a goal, (2) problem solving as a process and (3) problem solving as basic skill.[2]

In the opinion of NCTM,

Problem solving means engaging in a task for which the solution method is not known in advance. In order to find a solution, students must draw on their knowledge, and through this process, they will often develop new mathematical understandings. Solving problems is not only a goal of learning mathematics but also a major means of doing so [3].

According to Brownell opinion [4], a problem is not said to have been solved because the solution has been made. A problem is trully solved if the problem solver really understand what he has done to solve the problem and know sure why his steps were correct. This means that a new problem is actually said to have been solved by a student if the student has understood what he is doing, namely understanding the problem solving process and understanding why the solution has been appropriate.

Problem solving stimulates students to want to think, analyze a problem so that they can determine the solution. Shin Yi Lee stated that teaching mathematics through this method create a learning atmosphere in which students can explore problems on their own thinking and discover ways to complete the problems [5]. Problem solving creates learning environment for students to explore problems by themselves. Xuehui Xie also give opinion that problem solving means being involved in a task where the solution method is not known before hand. In order to find solution, students must figure the problem on their own knowledge, and through this process, they will create new understanding of mathematics. The process of solving problem is the heart for learning mathematics [3].

Problem solving can be interpreted as an effort or an approach to find a way out of a difficulty. Problem solving not only uses and applies a math formula or concepts, but also needs other aspects such as reasoning, creative thinking, analysis and synthesis. Students are encouraged and given the widest opportunity to take the initiative and think systematically in dealing with a problem by applying knowledge they gained previously.

The first step in solving math problems is understanding the problem. Understanding the problem involves three schemas, namely: 1) contextual schemes related to problem situations, 2) language schemes to understand what questions are from the problem, 3) mathematical schemes related to implied action from problems [6].

\section{METHODS}

\section{A. Research Design}

Design used in this study was a semi-experimental. Thus, it did not allow researcher to manipulate or control all relevant variables [7], [8]. In this study two classes were needed, namely experimental class and control class. Independent variable of this study was the treatment using problem solving methods in experimental class and treatment using expository method in the control class. Dependent variable was student's learning achievement on the topic of fraction.

\section{B. Site and Participant}

The site used was SMP Negeri 16 Surakarta. The population were 7th grade students of SMP Negeri 16 Surakarta. Results of this sample study were then used to generalize the entire population. 
Sampling was carried out by cluster random sampling technique that is subjected to successive units or subpopulations. These population units are called clusters. Of the 6 classes available, then drawn to get two classes. After that, lottery was done to determine which class will be used as control class and experimental class.

\section{Data Collection Technique}

In this study, the techniques used in data collection were as follows:

\section{a. Documentation}

The documentation method was used to obtain data about students'initial abilities, taken from the score of National Final Examination (UAN) of students'mathematics achievement. The data obtained were used to test the mean balance of the initial ability of the experimental group and the control group.

\section{b. Test}

The test was used to obtain data of students' mathematics learning achievement on the topic of fraction. The test used were objective and essay test.

\section{Data Analysis}

\section{Balance Test}

This test was carried out before the experimental class and control class had been subjected to treatment. This test aimed to find out whether the two classes are balanced or not. The data used for the balance test was taken from the documentation of the National Final Examination (UAN) for elementary school. Before the balance test was carried out, normality and homogeneity test were done first.

\section{Prerequisite Test Analysis}

\section{a. Normality test}

The normality test aimed to find out whether the research sample was taken from the population with normal distribution or not. Normality test uses the Lilliefors method. The reason for choosing the Lilliefors test is because this test can be used for small size samples.

\section{b. Homogeneity Test}

The homogeneity test was done to test whether the population was homogeneous or not, in other words having same variance or not. The method used was Bartlett method.

\section{Hypothesis testing}

To test the significance of differences in treatment effect of the learning method was used independent-samples t-test statistic with a significance level of $5 \%$.

\section{RESULT AND DISCUSSION}

After taking the sample, two classes namely class 7E was subjected to the problem solving method and class 7B was subjected to the expository method. Descriptions of UAN data of students are presented in Table 1 below,
Table 1. Descriptions of UAN data of students' mathematics achievement

\begin{tabular}{|c|c|c|c|c|c|}
\hline \multirow{2}{*}{ Class } & \multirow{2}{*}{$\mathrm{N}$} & \multicolumn{3}{|c|}{ Central Tendency } & Dispertion \\
\cline { 3 - 6 } & & Average & Modus & Median & $\begin{array}{c}\text { Standard } \\
\text { Deviation }\end{array}$ \\
\hline Exp & 30 & 90 & 95 & 90 & 6,09 \\
\hline Cont & 30 & 88,58 & 87,5 & 90 & 5,44 \\
\hline
\end{tabular}

Balance testing was done to find out whether the two samples have the same initial conditions. Before the balance test was performed, each sample was first tested whether it is normally distributed or not. The normality test uses the Liliefors method with a significant level of 0.05 . After the normality test, homogeneity test was carried out. Homogeneity test uses the Bartlet method with Chi Square test statistic with a significance level of $5 \%$.

Normality and homogeneity test results show that both class are normal and homogeneous, meaning that it has fulfilled the prerequisites for performing a balance test. Then a balance test was carried out on both classes. The results is tobs $=-0.9503$ that is not included in the Critical Region (DK), because $\mathrm{DK}=\{\mathrm{t} \mid \mathrm{t}<-1.96$ or $\mathrm{t}>1.96\}$. Thus, the decision taken is that $\mathrm{H}_{0}$ is accepted. This means that the experimental class and the control class have a balanced initial condition.

After being given treatment, then cognitive test was performed to the two classess to obtain data of students' achievement. The description of the data is presented in Table 2 below.

Table 2. The description of data of mathematics achievement score based on learning methods

\begin{tabular}{|c|c|c|c|c|c|}
\hline \multirow{2}{*}{ Class } & \multirow{2}{*}{$\mathrm{N}$} & \multicolumn{3}{|c|}{ Central Tendency } & Dispertion \\
\cline { 3 - 6 } & & Average & Modus & Median & $\begin{array}{c}\text { Standard } \\
\text { Deviation }\end{array}$ \\
\hline Exp & 30 & 70,54 & 63,33 & 69 & 12,59 \\
\hline Cont & 30 & 68,01 & 88,33 & 70 & 15,92 \\
\hline
\end{tabular}

The normality test and homogeneity test on students' mathematics learning achievement data were then preformed before testing hypothesis. The result is data are normal and homogeneous. Hypothesis testing used was independent samples t-test with a significance level of 5\%. T-test hypothesis is as follows:

$\mathrm{H}_{0}: \mu_{1}=\mu_{2}$ (there is no difference in the average learning achievement between problem solving classes and expository classes)

$\mathrm{H}_{1}: \mu_{1}>\mu_{2}$ (average learning achievement on problem solving class is better than expository class) 
T-test results using SPSS is as in Fig.1:

Independent Samples Test
\begin{tabular}{|c|r|r|r|r|}
\hline \multicolumn{4}{|c|}{ t-test for Equality of Means } \\
\hline $\mathrm{t}$ & $\mathrm{df}$ & Sig. (2-tailed) & $\begin{array}{c}\text { Mean } \\
\text { Difference }\end{array}$ & $\begin{array}{c}\text { Std. Error } \\
\text { Difference }\end{array}$ \\
\hline, 685 & 58 &, 496 & 2,53833 & 3,70559 \\
.685 & 55,067 &, 496 & 2,53833 & 3,70559 \\
\hline
\end{tabular}

Fig.1 Independent Samples t-test output using SPSS

From the results of independent samples t-tests on SPSS the results of sig. (2-tailed) $=0.496$ and for one tailed test the value of sig. (1-tailed) is $0.248>0.05$ thus, the decision taken is $\mathrm{H}_{0}$ accepted. Thus, it shows that problem solving produce learning achievement in mathematics as good as expository methods on the topics of fraction. This is contrary to the expected research hypothesis, (namely: the learning of mathematics on the subject of fractions by using problem solving methods will provide better mathematics learning achievement compared to mathematics learning using the expository method). Similar results between problem solving methods and lecture methods can be caused by the following factors:

1. Students need more time to adjust to problem solving learning methods.

This is possible because of the limited time for students to adjust to the problem solving method while students have long been accustomed to using the expository method where students just sit listening to the teacher's explanation and record what the teacher wrote on the board. The limitation of time was due to the amount of time that had been taken to learn the previous subject, so it was necessary to accelerate the time to catch up so that all the material in the semester could be entirely delivered to students. Teacher had problem in managing time.

2. The process of discussion and presentation is not going well.

Previously, students had never had a discussion in mathematics learning, discussion in mathematics was a new thing for students, so students were not used to conveying their ideas in working on questions. This causes the ability of students not to be well trained. When group discussions took place there were often students who only imitate the answers of their clever friends without wanting to understand the concept. This is proven by the fact that there are only a few students who can explain the results of the group discussion, so that students become less able to understand the material being taught. The teacher had formed a group by paying attention to various aspects, but still there were students who were active but make noise in the class, and there were students who were passive in the group. When presenting the results of the discussion in front of the class, there were still students who were shy and lacking in confidence. Students were less able to compose words in delivering their ideas, as a result other students misinterpret the ideas presented by their friends.
3. Students are not accustomed to being asked to do quizzes, so students are less serious in working on the quiz given by the teacher. As a result students are less able to develop their thinking and understanding of the material being taught.

In addition to the three factors above, other factors that are not research variables, which are uncontrolled, may influence the achievement of students' mathematics learning. These factors include intelligence, learning style, tutoring, learning creativity, and others.

\section{CONCLUSION AND RECOMMENDATION}

Based on theoretical studies and supported by the results of the analysis, researcher concluded that problem solving methods provide learning achievements that are as good as expository learning methods on the topic of fraction. Eventhough the marginal average shows that the marginal average of problem solving calss is higher than the marginal average of expository class, but the difference in the average score does not have a significant effect on student achievement.

Although learning mathematics by using problem solving methods produces learning achievements that are as good as learning mathematics by using the expository method, but there are some advantages of problem solving methods that can be used as consideration for choosing it as a method in classroom learning. The advantages are:

1. The teaching and learning process through problem solving can familiarize students to face and solve problems skillfully when facing problems in family life, community and work later.

2. This method stimulates the development of students' thinking skills creatively and comprehensively, because in the learning process, students do a lot of mental processes by highlighting problems from various aspects in order to find solutions.

The results of this study can be used as input for teachers and prospective teachers in an effort to improve the quality of the teaching-learning process. By paying attention to the factors that may affect teaching and learning process, teacher can choose the appropriate, effective and efficient method.

Teachers must be able to select several learning methods by considering a number of things: subject matter, the level of cognitive development of students, the condition of students and existing facilities, the allocation of time, the environment, and so on. Teachers can choose learning methods that support their need so that students' mathematics learning achievement can be achieved optimally.

\section{REFERENCES}

[1] Polya. G, How to Solve It, New Jersey: Princeton University Press, 1973.

[2] Branca. N A, Problem solving as a goal, process, and basic skill dalam Krulik, S. \& Reys, R. E. (editor), Problem solving in school mathematics, New York: the National Council of Teachers of Mathematics, Inc, 1980.

[3] Xie. Xuehui, "The Cultivation of Problem-solving and Reason in NCTM and Chinese National Standards. International Journal for 
Mathematics Teaching and Learning" Diperoleh 16 Desember 2015 dari http://www.cimt.plymouth.ac.uk/journal/xuehuixie.pdf, 2004.

[4] Mahmudi. A, Pengaruh Pembelajaran dengan Strategi MHM Berbasis Masalah terhadap Kemampuan Berpikir Kreatif, Kemampuan Pemecahan Masalah, dan Disposisi Matematis, serta Persepsi Terhadap Kreativitas, Disertasi, UPI Bandung. Tidak dipublikasikan, 2010.1

[5] Lee. Shin-Yi, "The Effect of Alternative Solutions on Problem Solving Performance", International Journal for Mathematics Teaching and Learning, Accessed 1 Juni 2013 http://www.cimt.plymouth.ac.uk/journal/lee.pdf, 2011.

[6] Purwanto. S.E, Meningkatkan Kemampuan Pemecahan Masalah Matematis Siswa SMP dan MTs melalui Pembelajaran Matematika Realistic, Disertasi, UPI Bandung. Tidak dipublikasikan, 2010.

[7] Fraenkel, Jack R and Wallen, Norman E, How to Design and Evaluate Research in Education, United States of America : The McGraw-Hill Companies, 2000.

[8] Emzir, Metodologi Penelitian Pendidikan Kuantitatif dan Kualitatif, Jakarta : PT RajaGrafindo Persada, 2008 